\title{
MENINGKATKAN KEMAMPUAN PEMAHAMAN DAN PEMECAHAN MASALAH MATEMATIS SISWA SD KELAS V MELALUI PENDEKATAN MATEMATIKA REALISTIK
}

\section{Kartika Fitriani' \& Maulana ${ }^{2}$}

I SDN Neglasari Kec. Conggeang

Desa Babakan Asem, Conggeang

Email: fitrianikartika@ymail.com

2 Program Studi PGSD UPI Kampus Sumedang

Jl. Mayor Abdurachman No. 211 Sumedang

Email: ae.maulana@gmail.com

\begin{tabular}{|c|c|}
\hline ABSTRACT & ABSTRAK \\
\hline $\begin{array}{l}\text { This research is cunducted to all fifth grade } \\
\text { elementary school students throughout the } \\
\text { Subdistrict Conggeang that included higher } \\
\text { group. The research result indicates that the } \\
\text { realistic mathematics education and } \\
\text { conventional approach give diffirent effect to } \\
\text { students' mathematical understanding and } \\
\text { problem solving abilities. The effect to } \\
\text { mathematical understanding and problem } \\
\text { solving ability in experiment class is better than } \\
\text { the control one. The effect of realistic } \\
\text { mathematics education to the higher, middle, } \\
\text { and lower achievement students group is } \\
\text { different too. Higher group gets bigger effect } \\
\text { than others. There is a positive correalaton } \\
\text { between mathematical understanding and } \\
\text { problem solving abilities, which its contribution is } \\
95,9 \% \text {. }\end{array}$ & 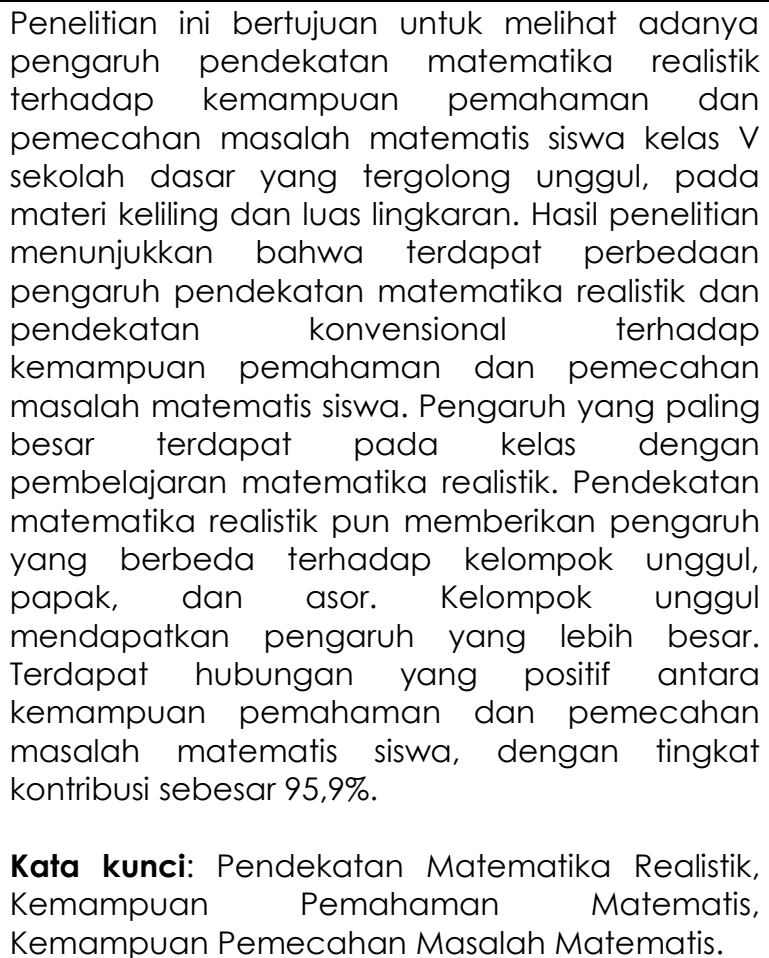 \\
\hline
\end{tabular}

How to Cite: Fitriani, K., \& Maulana, M. (2016). MENINGKATKAN KEMAMPUAN PEMAHAMAN DAN PEMECAHAN MASALAH MATEMATIS SISWA SD KELAS V MELALUI PENDEKATAN MATEMATIKA REALISTIK. Mimbar Sekolah Dasar, 3(1), 40-52. doi:http://dx.doi.org/10.17509/mimbar-sd.v3il.2355.

PENDAHULUAN Matematika merupakan salah satu mata pelajaran yang dirasakan oleh peserta didik sulit untuk diserap dan dipahami (Abdi, 2004). Menurut Maulana (2014) sulitnya memahami pelajaran matematika itu diperkirakan berkaitan dengan cara mengajar guru di kelas yang tidak membuat peserta didik merasa senang dan simpatik terhadap matematika, pendekatan yang dilakukan guru matematika pada umumnya kurang bervariasi. Padahal di sisi lain matematika merupakan mata pelajaran yang berguna bagi dirinya sendiri dan juga bagi mata 
Kartika Fitriani \& Maulana, Meningkatkan Kemampuan Pemahaman dan Pemecahan Masalah...

pelajaran lain, bahkan matematika dapat digunakan untuk membantu manusia dalam memecahkan masalah. Kline (dalam Ruseffendi, 1990, p. 2) menyebutkan, "Matematika itu bukan pengetahuan menyendiri yang dapat sempurna karena dirinya sendiri, tetapi beradanya itu terutama untuk membantu manusia dalam memahami dan menguasai permasalahan sosial, ekonomi, dan alam". Pendapat ini juga di dukung oleh Peraturan Menteri Pendidikan Nasional (2006a) yang menjelaskan bahwa standar kompetensi dan kompetensi dasar matematika di KTSP disusun untuk mengembangkan kemampuan menggunakan matematika dalam pemecahan masalah dan mengkomunikasikan ide atau gagasan dengan menggunakan simbol, tabel, diagram dan media lain.

Berdasarkan pemaparan sebelumnya jelaslah bahwa kemampuan pemecahan masalah matematis penting untuk dimiliki oleh siswa. Namun, berdasarkan hasil penelitian yang dilakukan oleh Jufriyah (2008) di SDN 1 Lungbenda Kecamatan Palimanan Kabupaten Cirebon, diketahui bahwa kemampuan pemecahan masalah siswa masih sangat rendah, dengan nilai rata-rata pada saat pengambilan data awal sebesar 12,59. Setelah mengalami pembelajaran dengan tiga siklus diperoleh peningkatan yaitu menjadi 50,81. Berdasarkan data tersebut diketahui bahwa kemampuan pemecahan masalah siswa yang rendah, kemudian memperoleh pembelajaran dengan pendekatan kontekstual sebanyak tiga siklus ternyata hasilnya masih rendah. Penyebab rendahnya kemampuan pemecahan masalah matematis ini adalah karena pelaksanaan pembelajaran selama ini masih belum mengarahkan siswa untuk dapat mengembangkan kemampuan pemecahan masalah, selain itu siswa belum terbiasa dengan soal-soal pemecahan masalah, sehingga siswa merasa kebingungan untuk dapat menyelesaikan soal pemecahan masalah.

Kemampuan lain yang tidak kalah pentingnya dibandingkan dengan kemampuan pemecahan masalah matematis siswa adalah kemampuan pemahaman matematis siswa. Menurut Peraturan Menteri Pendidikan Nasional (2006b) yang menyebutkan bahwa salah satu tujuan pembelajaran matematika adalah memahami konsep matematika, sehingga guru harus mampu membuat siswa paham akan konsep matematika bukan hanya sekadar hafal saja. Namun sayangnya di tingkat sekolah dasar kemampuan ini masih belum dimiliki secara utuh oleh siswa. Hal ini sesuai dengan hasil penelitian yang dilakukan Humardani (2010) di Kecamatan Susukan Kabupaten Cirebon yang menjelaskan bahwa rata-rata nilai tes kemampuan pemahaman siswa pada saat pretes sebesar 39,16, setelah dilaksanakan pembelajaran dengan menggunakan model Contextual Teaching and Learning (CTL) diperoleh peningkatan sehingga 
diperoleh hasil sebesar 60,14. Meskipun terjadi peningkatan namun tampak bahwa nilai tersebut masih rendah. Hal ini karena pembelajaran yang diterima oleh siswa masih belum optimal, sehingga hasil yang diperoleh siswa pun tidak optimal.

Untuk mengembangkan kemampuan pemahaman dan pemecahan masalah matematis siswa, dipilihlah pendekatan matematika realistik yang akan diterapkan di kelas $\vee$ pada materi keliling dan luas lingkaran. Pendekatan matematika realistik dipilih karena pendekatan ini akan mengarahkan siswa untuk dapat menemukan sendiri konsep berdasarkan konteks yang disajikan karena konteks yang disajikan saling terhubung dengan konsep lainnya sehingga diharapkan siswa akan memahami konsep secara keseluruhan, termasuk pada penerapannya. Selain itu, pendekatan matematika realistik juga berorientasi pada aktivitas pemecahan masalah. Dalam tahapan pembelajarannya pun terlihat jelas adanya tahapan pemecahan masalah.

Penelitian ini bertujuan untuk melihat adanya pengaruh pendekatan matematika realistik terhadap kemampuan pemahaman dan pemecahan masalah matematis siswa kelas $\mathrm{V}$ pada materi keliling dan luas lingkaran. Secara rinci tujuan dari penelitian ini adalah sebagai berikut.

1. Untuk mengetahui perbedaan pengaruh pendekatan matematika realistik dan pendekatan konvensional terhadap kemampuan pemahaman matematis siswa pada materi keliling dan luas lingkaran.

2. Untuk mengetahui perbedaan pengaruh pendekatan matematika realistik dan pendekatan konvensional terhadap kemampuan pemecahan masalah matematis siswa pada materi keliling dan luas lingkaran.

3. Untuk mengetahui perbedaan pengaruh pendekatan matematika realistik terhadap kemampuan pemahaman matematis siswa kelompok unggul, papak dan asor pada materi keliling dan luas lingkaran.

4. Untuk mengetahui perbedaan pengaruh pendekatan matematika realistik terhadap kemampuan pemecahan masalah matematis siswa kelompok unggul, papak, dan asor pada materi keliling dan luas lingkaran.

5. Untuk mengetahui hubungan yang positif antara kemampuan pemahaman dan kemampuan pemecahan masalah matematis siswa.

Gunawan (2013a) menyebutkan bahwa RME adalah suatu teori pembelajaran matematika yang beranggapan bahwa matematika adalah aktivitas manusia serta matematika harus dihubungkan terhadap konteks kehidupan sehari-hari siswa yang menggunakan proses matematisasi horizontal maupun vertikal untuk mengembangkan konsep dan mengaplikasikannya. Pendapat lain menyebutkan bahwa, pendekatan 
Kartika Fitriani \& Maulana, Meningkatkan Kemampuan Pemahaman dan Pemecahan Masalah...

matematika realistik merupakan pendekatan pembelajaran yang berorientasi pada penalaran siswa dalam menyelesaikan masalah yang bersifat realistik yang ditujukan untuk mengembangkan pola pikir praktis, logis, kritis, dan jujur (Tarigan, 2006). Berdasarkan pendapat di atas maka dapat disimpulkan bahwa, pendekatan matematika realistik adalah pendekatan pembelajaran yang berorientasi pada aktivitas pengkonstruksian pengetahuan dengan menghubungkan antar konsep untuk memecahkan masalah yang berhubungan dengan aktivitas manusia yang berguna untuk mengembangkan pola pikir praktis, logis, kritis, dan jujur dengan menggunakan konteks dari lingkungan dalam mengajarkan konsepnya. Oleh karena itu dalam pendekatan realistik masalah yang berhubungan dengan dunia nyata siswa diangkat sebagai titik awal pembelajaran dan siswa dituntut untuk mampu memecahkan masalah agar dapat menemukan konsep yang diajarkan.

Siswa SD berada pada tahap operasional konkret. Pada tahapan ini, konsep akan dikembangkan dengan menggunakan benda-benda konkret untuk menyelidiki hubungan dan model-model ide abstrak (Maulana, 2011). Pada tahap ini anak sudah mampu berpikir logis, akibat kegiatannya dalam memanipulasi bendabenda konkret. Teori Piaget ini sejalan dengan pendekatan matematika realistik karena pembelajarannya menggunakan konteks yang berasal dari lingkungan siswa. Konteks yang disajikan bisa berupa masalah, permainan, bahkan berupa benda konkret yang dapat dimanipulasi oleh siswa secara langsung. Dengan demikian siswa akan lebih mudah dalam memahami konsep yang dijelaskan.

Prinsip pendekatan matematika realistik disampaikan oleh Suryanto, dkk. (2010) yaitu: a) guided re-invention (penemuan kembali secara terbimbing) dan progressive Mathematization (matematisasi progresif); b) didactical phenomenology (fenomenologi didaktis); serta c) self-developed model (membangun sendiri model). Maksudnya adalah melalui masalah realistik yang diberikan guru, siswa dibimbing untuk menemukan kembali konsep matematika melalui kegiatan matematisasi horizontal dan vertikal. Tujuan utama pendekatan matematika realistik adalah pengalaman belajar yang bermakna bagi siswa dan sikap positif siswa terhadap matematika. Karena siswa memiliki kebebasan dalam memecahkan masalah realistik yang disajikan guru, maka sangat memungkinkan siswa mengembangkan model sendiri.

Kata konvensional menurut Tim Penyusun Kamus Pusat Bahasa (2005) adalah umum atau seperti kebiasaan, kelaziman. Oleh karena itu, yang dimaksud dengan pendekatan pembelajaran konvensional dalam penelitian ini adalah pendekatan pembelajaran yang sudah biasa 
dipergunakan di sekolah tempat penelitian dilaksanakan. Kegiatan pembelajaran yang biasa dilakukan pada tempat penelitian adalah pembelajaran dengan menggunakan metode ekspositori. Menurut Maulana (2011), dalam pembelajaran dengan menggunakan metode ekspositori, guru menjelaskan dan menyampaikan informasi, pesan, atau konsep kepada seluruh siswa baik secara lisan maupun tulisan. Dengan demikian, pembelajaran konvensional akan menuntut siswa untuk memiliki kemampuan menyimak yang baik.

Kemampuan yang dibahas dalam penelitian ini adalah kemampuan pemahaman dan pemecahan masalah matematis siswa. Kemampuan pemahaman matematis merupakan salah satu kemampuan matematis yang penting dimiliki oleh siswa termasuk pada jenjang sekolah dasar. Menurut Kamus Besar Bahasa Indonesia (2005: p. 811) pemahaman berasal dari kata paham yang artinya proses, cara, perbuatan memahami atau memahamkan. Driver (dalam Gunawan, 2013b) menyebutkan bahwa, pemahaman adalah kemampuan menjelaskan suatu situasi atau suatu tindakan. Berdasarkan beberapa pendapat tadi maka dapat disimpulkan bahwa, kemampuan pemahaman matematis adalah kemampuan seseorang dalam mengingat, memahami, menjelaskan, dan menerapkan konsep matematika untuk menyelesaikan masalah dalam kehidupan sehari-hari. Adapun indikator yang akan digunakan untuk mengukur kemampuan pemahaman matematis siswa dalam penelitian ini adalah sebagai berikut ini.

1. Mampu menerapkan rumus dalam perhitungan matematis dan dapat melakukan pengerjaan hitung. Dalam indikator yang pertama ini diharapkan, (a) siswa mampu menuliskan rumus keliling dan luas lingkaran, (b) siswa dapat menerapkan rumus tersebut pada kasus-kasus matematis, dan (c) siswa dapat menghitung hasil atau pemecahan masalah dari kasus yang ditemui.

2. Mampu mengaitkan konsep dengan konsep yang lainnya dan menyadari proses yang dikerjakan. Dalam indikator yang kedua ini diharapkan, (a) siswa mampu untuk menggunakan konsep matematis yang telah dipelajari sebelumnya, dan (b) siswa mampu menghubungkan konsepkonsep tersebut dan menyadari tujuan dari semua keterkaitan antara proses yang sudah dirumuskan.

Menurut Dahar (dalam Kesumawati, 2010) dalam pemecahan masalah manusia akan menggabungkan konsep-konsep dan aturan-aturan yang telah diperoleh sebelumnya untuk menyelesaikan masalah yang dihadapinya. Sementara Polya (dalam Kesumawati, 2010) menyebutkan bahwa pemecahan masalah merupakan suatu usaha mencari jalan keluar dari suatu kesulitan yang 
Kartika Fitriani \& Maulana, Meningkatkan Kemampuan Pemahaman dan Pemecahan Masalah...

sedang dihadapi. Berdasarkan pendapat tersebut maka, kemampuan pemecahan masalah matematis yang dimaksudkan dalam penelitian ini adalah kemampuan siswa untuk mencari dan mengolah informasi, serta memilih dan menerapkan strategi yang tepat untuk menemukan solusi dari masalah realistik yang ditemukan, dengan berbekal pengetahuan awal yang sudah dimilikinya. Kemampuan pemecahan masalah ini sesuai dengan teori yang disampaikan Gagne (dalam Maulana, 2011) yang berpendapat bahwa, belajar dikelompokkan ke dalam delapan tipe belajar salah satunya adalah tipe pemecahan masalah. Adapun indikator kemampuan pemecahan masalah dalam penelitian ini adalah sebagai berikut.

1. Mengidentifikasi kecukupan data untuk pemecahan masalah yaitu siswa diharapkan mampu menuliskan unsur yang diketahui dan ditanyakan serta melengkapi unsur apa yang dibutuhkan untuk memecahkan masalah yang tidak tercantum di dalam soal.

2. Merumuskan masalah atau menuliskan model matematika dari masalah yang ditemui yaitu siswa mampu menuliskan model matematika dari permasalahan yang ditemuinya.

3. Memilih dan menerapkan strategi untuk menyelesaikan masalah matematika atau di luar matematika yaitu siswa dapat memilih strategi untuk memecahkan masalah termasuk didalamnya melengkapi data yang dibutuhkan untuk memecahkan masalah dan menerapkan strategi yang sudah dipilihnya dengan urutan tepat.

4. Menyelesaikan masalah yang muncul di dalam matematika atau di dalam konteks lain yang melibatkan matematika yaitu siswa mampu menerapkan rumus untuk memecahkan masalah matematika sederhana berdasarkan data-data yang sudah terkumpul dan siswa dapat memecahkan masalah berdasarkan data-data yang sudah terkumpul dengan menggunakan strategi yang dipilih.

5. Memeriksa kebenaran hasil atau jawaban di mana siswa mampu menyatakan suatu pemecahan masalah itu benar atau salah dengan alasan yang benar.

Salah satu materi yang diajarkan di kelas $\mathrm{V}$ SD adalah tentang lingkaran. Lingkaran adalah bangun datar bersisi satu, berupa garis lengkung. Hal ini sejalan dengan yang disampaikan Permana \& Triyati (2008) bahwa, lingkaran adalah bangun datar yang terdiri dari garis lengkung di mana titik-titiknya berjarak tetap terhadap suatu titik tertentu yang disebut titik pusat lingkaran. Keliling lingkaran adalah ukuran tepian luar lingkaran yang diukur mulai dari satu titik hingga kembali ke titik tersebut dalam satu kali putaran. Sementara luas lingkaran adalah besarnya ukuran bidang yang dibatasi kurva lingkaran. 


\section{METODE}

Metode penelitian yang digunakan adalah metode penelitian eksperimen dengan desain kelompok kontrol hanyapostes (posttest only control group design). Populasi dalam penelitian ini adalah siswa kelas V SD se-Kecamatan Conggeang Kabupaten Sumedang Tahun Ajaran 2014/2015 yang termasuk ke dalam kelompok unggul, sedangkan sampel dalam penelitian ini adalah siswa kelas $\mathrm{V}$ SDN Conggeang 1 dan SDN Cibubuan 2. Pemilihan sampel ini dilakukan dengan cara random berkelompok.

Instrumen yang digunakan adalah soal tes uraian dan pedoman observasi. Instrumen soal diuji validitas, reliabilitas, tingkat kesukaran, dan daya pembeda. Data yang diperoleh dari hasil tes kemampuan matematis diolah untuk mencari tahu kelompok siswa unggul, papak dan asor, serta untuk penentuan nilai KKM. Untuk hasil tes kemampuan pemecahan masalah matematis kemudian diolah dengan cara mencari normalitas, homogenitas, dan perbedaan rataratanya. Sementara untuk instrumen nontes diolah dengan cara menyimpulkannya.

\section{HASIL DAN PEMBAHASAN}

Penelitian diawali dengan pemberian tes kemampuan matematis siswa untuk mengetahui kemampuan siswa dalam menguasai materi prasyarat. Dengan adanya tes ini diketahui bahwa jumlah siswa yang termasuk kelompok unggul sebanyak 14 orang, yang terdiri dari tujuh orang kelas eksperimen dan tujuh orang kelas kontrol. Siswa yang termasuk ke dalam kelompok papak sebanyak 40 orang, yang terdiri dari 18 orang siswa dari kelas eksperimen dan 22 orang dari kelas kontrol. Untuk siswa yang termasuk ke dalam kelompok asor berjumlah delapan orang, yang terdiri dari tujuh orang kelas eksperimen dan satu orang dari kelas kontrol. Selain itu, nilai KKM untuk materi keliling dan luas lingkaran ini adalah 33,33.

Pembelajaran keliling dan luas lingkaran dengan menggunakan pendekatan matematika realistik untuk meningkatkan kemampuan pemecahan masalah matematis siswa dilaksanakan sebanyak tiga pertemuan. Pertemuan pertama membahas konsep lingkaran, menggambar lingkaran, dan mencari titik pusat lingkaran. Pertemuan kedua membahas materi keliling lingkaran. Pertemuan ketiga membahas materi luas lingkaran. Dari ketiga pertemuan tersebut diketahui bahwa persentase aktivitas guru di kelas eksperimen sebesar 95,24\% diinterpretasikan sangat baik, dan aktivitas guru di kelas kontrol sebesar 94,74\%, diinterpretasikan sangat baik pula. Sementara, untuk aktivitas siswa di kelas eksperimen dan kontrol diinterpretasikan sangat baik dengan persentase aktivitas siswa kelas eksperimen sebesar $94,44 \%$ dan kelas kontrol sebesar $91,67 \%$.

Kegiatan akhir yang dilakukan setelah pembelajaran selesai adalah pemberian 
Kartika Fitriani \& Maulana, Meningkatkan Kemampuan Pemahaman dan Pemecahan Masalah...

soal posttest yang berisi soal tes kemampuan pemahaman dan pemecahan masalah matematis.
Berdasarkan hasil tes diperoleh data sebagai berikut ini.

Tabel 1. Nilai TKM dan Posttest

\begin{tabular}{|l|c|c|c|c|c|c|c|c|c|}
\hline \multirow{2}{*}{ Kelas } & \multicolumn{3}{|c|}{ Nilai TKM } & \multicolumn{3}{c|}{ Nilai Posttest Pemahaman } & \multicolumn{3}{c|}{ Nilai Posttest Pemecahan } \\
\cline { 2 - 11 } & \multirow{2}{*}{ Tertinggi } & Terendah & $\bar{x}$ & Tertinggi & Terendah & $\bar{x}$ & Tertinggi & Terendah & $\bar{x}$ \\
\hline Eksperimen & 83,82 & 4,41 & 32,81 & 91,07 & 26,79 & 70,03 & 92,13 & 19,10 & 63,27 \\
\hline Kontrol & 79,41 & 7,35 & 34,17 & 85,71 & 19,64 & 60,06 & 82,02 & 14,61 & 50,56 \\
\hline
\end{tabular}

Tabel 2. Nilai Kelompok Unggul, Papak, dan Asor

\begin{tabular}{|l|c|c|c|c|c|c|}
\hline \multirow{2}{*}{ Kelas } & \multicolumn{3}{|c|}{ Rata-rata Nilai Posttest Pemahaman } & \multicolumn{3}{c|}{ Rata-rata Nilai Posttest Pemecahan } \\
\cline { 2 - 7 } & Unggul & Papak & Asor & Unggul & Papak & Asor \\
\hline Eksperimen & 86,73 & 72,93 & 41,37 & 85,55 & 66,88 & 25,84 \\
\hline Kontrol & 78,83 & 55,93 & 19,64 & 75,60 & 44,23 & 14,61 \\
\hline
\end{tabular}

Setelah dilakukan tes kemudian dilaksanakan uji normalitas, sehingga diketahui bahwa data nilai tes kemampuan pemahaman matematis siswa kelas eksperimen dan kontrol berdistribusi tidak normal, sehingga tidak akan dilaksanakan uji homogenitas terhadap kedua nilai tersebut. Sedangkan untuk nilai tes kemampuan pemahaman matematis siswa kelompok unggul, papak dan asor ketiganya berdistribusi normal. Setelah pelaksanaan posttest juga diperoleh nilai tes kemampuan pemecahan masalah matematis siswa, setelah dilakukan uji normalitas diketahui bahwa nilai tes kemampuan pemecahan masalah matematis siswa kelompok eksperimen berdistribusi tidak normal, sementara kelas kontrol berdistribusi normal. Berdasarkan hasil perhitungan tersebut maka, tidak akan dilakukan uji homogenitas untuk kedua nilai tersebut. Hasil uji normalitas nilai tes kemampuan pemecahan masalah matematis siswa kelompok unggul, papak, dan asor, diketahui bahwa nilai kelompok unggul berdistribusi tidak normal sementarakelompok papak dan asor berdistribusi normal. Uji homogenitas pun tidak dilakukan terhadap nilai tersebut.

Untuk menjawab permasalahan yang pertama dilakukan uji beda rata-rata dengan menggunakan uji Mann-Withney (Uji U) terhadap nilai tes kemampuan pemahaman matematis siswa kelas eksperimen dan kontrol. Berdasarkan perhitungan diperoleh hasil P-value (sig) sebesar 0,012 artinya terdapat perbedaan pengaruh yang diberikan oleh pendekatan matematika realistik dan pendekatan konvensional terhadap kemampuan pemahaman siswa. Pengaruh yang paling besar diberikan oleh pendekatan matematika realistik. Hal ini tampak dari rata-rata nilai yang diperoleh kelas eksperimen lebih besar daripada kels kontrol yaitu sebesar 70,03 
dan 60,06 . Hal ini karena konsep yang diterima oleh siswa pada pendekatan konvensional hanya melalui kegiatan menyimak saja karena siswa pada pendekatan konvensional cenderung pasif, sementara pada pendekatan matematika realistik siswa mengkonstruksi sendiri pengetahuannya melalui kegiatan menghias benda yang memiliki permukaan berbentuk lingkaran, sehingga siswa mudah mengingat materi yang dipelajarinya. Kegiatan tersebut sejalan dengan teori perkembangan kognitif menurut Piaget, yang menyatakan bahwa siswa usia SD berada pada tahap operasional konkret, di mana siswa akan lebih mengerti konsep yang diajarkan dengan menggunakan benda-benda konkret. Selain itu, menurut sri (2011) pendekatan matematika realistik ini menggunakan pengalaman dan lingkungan sebagai alat bantu mengajar.

Untuk menjawab permasalahan yang kedua sama hal nya dengan masalah yang pertama, yaitu dengan melakukan uji beda rata-rata dengan uji U. Diperoleh hasil P-value (sig. 1-tailed) sebesar 0,005, artinya terdapat perbedaan rata-rata antara kelas eksperimen dan kelas kontrol, dengan demikian maka pendekatan matematika realistik dan pendekatan konvensional memberikan pengaruh yang berbeda terhadap kemampuan pemecahan masalah matematis siswa. Berdasarkan nilai rata-rata yang diperoleh diketahui bahwa kelas eksperimen mendapatkan pengaruh yang lebih besar karena nilai rata-ratanya lebih besar dibandingkan dengan kelas kontrol. Nilai yang dimaksud adalah 63,27 sedangkan kelas kontrol sebesar 50,56. Hal ini karena menurut Gagne (dalam Maulana, 2011) salah satu tipe belajar adalah tipe belajar pemecahan masalah, dan terdapat lima tahapan dalam pemecahan masalah yang harus di tempuh selama pembelajaran. Tahapan tersebut diadopsi dalam pendekatan matematika realistik.

Permasalahan yang ketiga dijawab dengan cara melakukan Uji Anova Satu Jalur dan dilanjutkan dengan Uji Scheffe untuk nilai tes kemampuan pemahaman matematis siswa kelompok unggul, papak, dan asor. Berdasarkan hasil Uji Anova Satu Jalur yang telah dilakukan diketahui bahwa $P$-value (sig.) sebesar 0,000 artinya terdapat perbedaan rata-rata nilai tes kemampuan pemahaman matematis siswa kelompok unggul, papak, dan asor. Setelah dilanjutkan Uji Scheffe diketahui bahwa pengaruh pendekatan matematika realistik terhadap kemampuan pemahaman matematis paling besar terdapat pada kelompok unggul, karena rata-rata yang diperoleh kelompok unggul sebesar 86,73, sementara kelompok papak 72,93 dan kelompok asor sebesar 41,37. Hal tersebut terjadi karena setelah pelaksanaan tes kemampuan matematis siswa diketahui bahwa ada beberapa siswa yang termasuk kelompok unggul, sebagian lagi kelompok papak dan asor. Siswa yang tadinya tergolong kelompok unggul 
Kartika Fitriani \& Maulana, Meningkatkan Kemampuan Pemahaman dan Pemecahan Masalah...

sangat memungkinkan menjadi kelompok unggul pula pada tes kemampuan pemahaman matematis siswa karena siswa tersebut sudah memiliki dasar untuk mengerjakan tes kemampuan pemahaman matematis, karena tes kemampuan matematis yang diberikan di awal pembelajaran merupakan tes untuk mengetahui kemampuan siswa dalam menguasai materi prasyarat. Selain itu dengan adanya kegiatan pembelajaran yang dilaksanakan di kelas akan menambah pengetahuan yang diperoleh siswa khususnya untuk melatih kemampuan pemahaman dan pemecahan masalah matematis siswa. Selama pembelajaran matematika realistik berlangsung kelompok unggul lebih cepat menangkap materi pembelajaran dan lebih cepat ketika melakukan kegiatan memanipulasi media. Berdasarkan pemaparan tersebut maka sangatlah memungkinkan siswa yang tadinya unggul akan menjadi unggul pula, begitupun dengan kelompok papak dan asor karena pengetahuan awal yang mereka miliki berbeda.

\begin{tabular}{|c|c|}
\hline $\begin{array}{ll}\text { gan mel } \\
\text { ngga } & \text { dipe } \\
\text { esar } & 0,0\end{array}$ & $\begin{array}{l}\text { yang } \\
\text { adanya perb } \\
\text { diberikan pend } \\
\text { realistik ter } \\
\text { pemecahan }\end{array}$ \\
\hline
\end{tabular}

perbedaan rata-rata nilai tes kemampuan pemecahan masalah matematis siswa kelompok unggul, papak, dan asor. Perngaruh yang paling besar diperoleh kelompok unggul karena nilai rata-ratanya paling besar, yaitu 85,55, sedangkan kelompok papak 66,88, dan kelompok asor 25,84. Perbedaan kemampuan ini sejalan dengan hasil tes kemampuan matematis siswa, dengan demikian maka siswa yang tadinya unggul kemampuan matematisnya kembali menjadi siswa yang unggul dalam kemampuan pemecahan masalahnya. Hal ini terjadi karena dalam tes kemampuan matematis siswa yang menjadi kelompok unggul adalah siswa yang dapat mengerjakan soal dengan optimal jika dibandingkan dua kelompok lainnya yaitu papak dan asor. Selain itu selama pembelajaran berlangsung, siswa kelompok unggul selalu lebih cepat dalam memecahkan masalah yang disajikan dalam pembelajaran, sehingga sangat memungkinkan siswa yang tadinya unggul akan menjadi kelompok unggul kembali setelah mengikuti tes kemampuan pemecahan masalah matematis siswa.

Permasalahan yang terakhir mencari tahu hubungan antara kemampuan pemahaman dan kemampuan pemecahan masalah matematis siswa. Uji yang dilakukan adalah uji koefisien korelasi Spearman karena salah satu data yang akan di uji berdistribusi tidak normal. Berdasarkan hasil uji Spearman diketahui bahwa hubungan antara kedua 
kemampuan tersebut sangatlah besar. Yaitu sebesar $95,9 \%$. Hubungan ini jelas dapat terbentuk karena salah satu tahapan dalam memecahkan masalah menurut Peraturan Menteri Pendidikan Nasional (2006b, p. 30) adalah pemahaman terhadap masalah. Pernyataan serupa juga disampaikan oleh Adjie \& Maulana (2006, p. 15) bahwa, salah satu keterampilan untuk meningkatkan kemampuan pemecahan masalah adalah memahami soal. Kegiatan memecahkan masalah dalam pendekatan matematika realistik siswa diarahkan untuk dapat memecahkan masalah dengan menggunakan pemahaman yang dimilikinya yang berkaitan dengan masalah yang disajikan. Selain itu jika dibandingkan nilai tes kemampuan pemahaman matematis siswa dengan nilai tes kemampuan pemecahan masalah diketahui bahwa jika nilai pemahaman matematisnya tinggi maka kemampuan pemecahan masalahnya pun tinggi, begitupun sebaliknya.

\section{SIMPULAN}

Pendekatan matematika realistik dan pendekatan konvensional memberikan pengaruh yang berbeda terhadap kemampuan pemahaman matematis siswa. Pengaruh yang lebih baik terdapat di kelas eksperimen yang memperoleh pembelajaran dengan menggunakan pendekatan matematika realistik. Hal ini tampak dari rata-rata nilai tes kemampuan pemahaman matematis siswa yang diperoleh kelompok eksperiman lebih tinggi daripada rata-rata nilai tes kemampuan pemahaman matematis siswa kelas kontrol. Karena pada pendekatan matematika realistik siswa mengkonstruksi pengetahuannya sendiri dengan memanfaatkan berbagai media yang berasal dari lingkungan sekitar siswa sehingga siswa akan lebih mudah dalam memahami dan mengingat pengetahuan yang diterimanya, selain itu dengan berbagai latihan soal yang berisi masalah yang realistik akan melatih kemampuan pemahaman matematis siswa, sementara dengan pendekatan konvensional akan menerima pengetahuan melalui penjelasan guru dan latihan-latihan soal.

Pendekatan matematika realistik dan pendekatan konvensional juga memberikan pengaruh yang berbeda terhadap kemampuan pemecahan masalah matematis siwa. Pengaruh yang lebih besar terjadi di kelas eksperimen yang menerapkan pendekatan matematika realistik karena memperoleh rata-rata nilai tes kemampuan pemecahan masalah matematis yang lebih besar daripada kelas kontrol. Hal ini karena pendekatan matematika realistik berorientasi pada pemecahan masalah, selama pembelajaran pun siswa diberikan latihan soal yang didalamnya terdapat masalah-masalah yang dapat dibayangkan siswa. Selain itu tahapan pembelajaran dalam pendekatan matematika realistik juga melatih 
Kartika Fitriani \& Maulana, Meningkatkan Kemampuan Pemahaman dan Pemecahan Masalah...

kemampuan pemecahan masalah matematis siswa.

Terdapat perbedaan pengaruh pendekatan matematika realistik terhadap kemampuan pemahaman matematis siswa di kelompok unggul, papak, dan asor. Kelompok unggul memperoleh pengaruh yang paling kuat karena rata-rata nilai yang diperolehnya pun terbesar. Sebelumnya siswa dikelompokkan berdasarkan nilai tes kemampuan pemahaman matematis, maka siswa yang kelompok unggul adalah siswa memiliki nilai paling tinggi saat tes kemampuan pemahaman matematis. Tes kemampuan matematis adalah tes untuk mengetahui kemampuan prasyarat siswa, dengan demikian jika siswa memperoleh nilai yang tinggi dalam tes kemampuan matematis siswa artinya siswa tersebut memiliki kemampuan awal yang bagus. Selain itu selama pembelajaran siswa kelompok unggul selalu cepat dalam kegiatan memanipulasi media dan memecahkan masalah.

Terdapat perbedaan pengaruh pendekatan matematika realistik terhadap kemampuan pemecahan masalah matematis siswa kelompok unggul, papak, dan asor. Pengaruh yang paling kuat diperoleh kelompok unggul, karena rata-rata nilai tes kemampuan pemecahan masalah matematis siswa yang tertinggi diperoleh kelompok unggul. Siswa yang unggul dalam tes kemampuan pemecahan masalah matematis ternyata dalam tes kemampuan matematis pun sebagian besar juga unggul, dengan demikian kemampuan dasar yang dimiliki kelompok unggul lebih baik dari awal dibandingkan dengan kelompok papak, dan asor. Ditambah lagi selama pembelajaran dengan menggunakan pendekatan matematika realistik siswa terus diasah kemampuan pemecahan masalah matematisnya melalui berbagai kegiatan pembelajaran dan juga melalui masalah yang disajikan dalam berbagai latihan soal.

Terdapat hubungan yang positif antara kemampuan pemahaman matematis dengan kemampuan pemecahan masalah matematis. Hubungan yang terbentuk sangat kuat, yakni sebesar 95,9\%. Hubungan tersebut terbentuk karena dalam memecahkan masalah salah satu tahapannya adalah siswa dituntut untuk memahami masalah yang disajikan. Selain itu, siswa harus menghubungkan masalah tersebut dengan konsep yang sudah dimiliki siswa sebelumnya untuk dapat memecahkan masalah.

\section{REFERENSI}

Abdi, A. (2004). Senyum Guru matematika dan Upaya Bangkitkan Gairah Siswa. [Online]. Tersedia: http://www.waspada.co.id/serba_serb i/ pendidikan/ artikel.php?article_id $=6722$

Gunawan, P. R. (2013a). Pendekatan pembelajaran realistic mathematic education (RME). [Online]. Diakses dari: http://proposalmatematika23.blogspot. 
com/2013/05/pendekatan-

pembelajaran-realistic.html.

Gunawan, P. R. (2013b). Kemampuan pemahaman matematik. [Online]. Diakses dari: http://proposalmatematika23.blogspot. com/2013/05/kemampuan-

pemahaman-matematik.html.

Humardani (2010). Implementasi model Contextual Teaching and Learning (CTL) untuk meningkatkan pemahaman siswa pada materi luas dan keliling lingkaran di kelas VI SDN 1 Bojongkulon Kec. Susukan Kabupaten Cirebon. (Skripsi). Universitas Pendidikan Indonesia.

Jufriyah, R. (2008). Penerapan pendekatan kontekstual untuk meningkatkan kemampuan memecahkan masalah soal cerita operasi hitung campuran siswa kelas IV SDN 1 Lungbenda Kecamatan Palimanan Kabupaten Cirebon. (Skripsi). Universitas Pendidikan Indonesia.

Kesumawati, N. (2010). Peningkatan kemampuan pemahaman, pemecahan masalah, dan disposisi matematis siswa SMP melalui pendekatan pendidikan matematika realistik. (Disertasi). Sekolah Pascasarjana Universitas Pendidikan Indonesia, Bandung.

Maulana (2011). Dasar-dasar keilmuan dan pembelajaran matematika sequel 1. Subang: Royyan Press.

Maulana, M. (2016). INTERAKSI PBLMURDER, MINAT PENJURUSAN, DAN KEMAMPUAN DASAR MATEMATIS TERHADAP PENCAPAIAN KEMAMPUAN BERPIKIR DAN DISPOSISI KRITIS. Mimbar Sekolah Dasar, 2(1), 1-18.

Ruseffendi, E. T. (1990). Pengajaran matematika modern dan masa kini seri kedua. Bandung: Tarsito.

Sri, S. (2011). Upaya Meningkatkan Hasil Belajar Siswa melalui Pendekatan Matematika Realistik dengan Menggunakan Kartu Pecahan pada Siswa Kelas IV Sekolah Dasar Negeri 3
Sugihan Semester II Tahun Pelajaran 2010/2011. (Skripsi). Salatiga: S1 PGSD UKSW.

Suryanto, dkk. (2010). Sejarah pendidikan matematika realistik Indonesia (PMRI). Yogtakarta: Dikti.

Tarigan, D. (2006). Pembelajaran matematika realistik. Jakarta: Depdiknas.

Tim Penyusun Kamus Pusat Bahasa (2005). Kamus Besar Bahasa Indonesia Jilid 3. Jakarta: Balai Pustaka.

Permana, D. \& Triyati (2008) . Bersahabat dengan matematika untuk kelas VI Sekolah Dasar/ Madrasah Ibtidaiyah. Jakarta: Pusat Perbukuan, Depdiknas.

Peraturan Menteri Pendidikan Nasional (2006a). Kurikulum 2006 (Peraturan Menteri Pendidikan Nasional Republik Indonesia Nomor 22 Tahun 2006 tentang Standar Isi untuk satuan Pendidikan Dasar. Jakarta: Depdiknas

Peraturan Menteri Pendidikan Nasional (2006b). Peraturan Menteri Pendidikan Nasional Republik Indonesia Nomor 23 Tahun 2006 Tanggal 23 Mei 2006. Jakarta: Depdiknas. 